\title{
Storhed og fald for Letlands økonomi
}

\section{Morten Hansen}

\section{Hvis Letland ikke kan gennemføre den interne devaluering med succes, ser det meget sort ud for Grækenland, Portugal, Spanien og Italien, der ikke har samme fleksible økonomier som Letland. Der er derfor al mulig grund til at følge udviklin- gen i Letland meget nøje}

Letland var det vel mest omtalte land i den Europæiske Union for så vidt angår økonomisk udvikling fra slutningen af 2008 til oktober 2009, hvor Grækenland overtog den tvivlsomme ære. Landet, der med unionens højeste vækstrater i 2004 2006, var en del af 'De Baltiske Tigre', så i 2008 økonomisk vækst forvandlet til recession og måtte ty til støtte fra Den Internationale Valutafond (IMF) og fra EU for at afværge såvel statsbankerot som et kollaps af både banksystemet og den lokale valuta. Hvorledes et land med en befolkning på kun 2,24 millioner kunne aftvinge en sådan interesse, og hvordan unionens største boom kunne forvandles til det størst bust er emnet for denne artikel.

\section{'Olympiske ubalancer'}

Den negative indvirkning på den lettiske økonomi fra den russiske krise i 1998-99, hvor Rusland devaluerede rublen med ca. 75 pct., blev relativt hurtigt overstået, og økonomien reorienterede sig kraftigt mod Vesten. En meget signifikant catch-up fase blev skabt, som det også ses af figur 1 .

Faktisk var vækstraterne i Letland i 2004-06 de højeste i hele EU. Denne meget høje vækst var dels et resultat af, at landet målt på BNP pr. indbygger kun var ca. en trediedel af gennemsnittet for EU27 (og derved det tredjefattigste land i EU27, kun foran Bulgarien og Rumænien) og således havde stort catch-up po- 
Figur 1: Årlig vækst i bruttonationalprokuktet

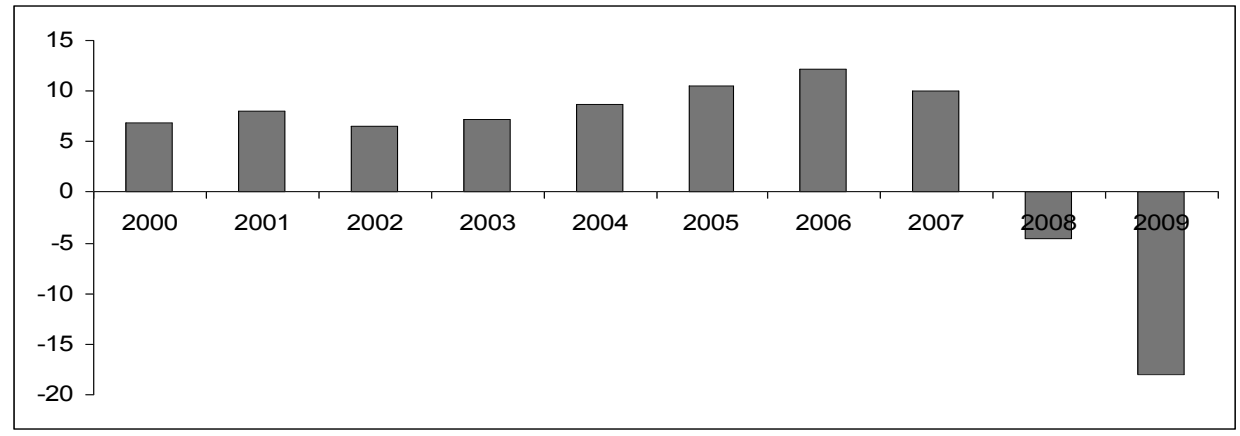

Figur 2: Årlig kredittilvækst til husholdninger og virksomhneder

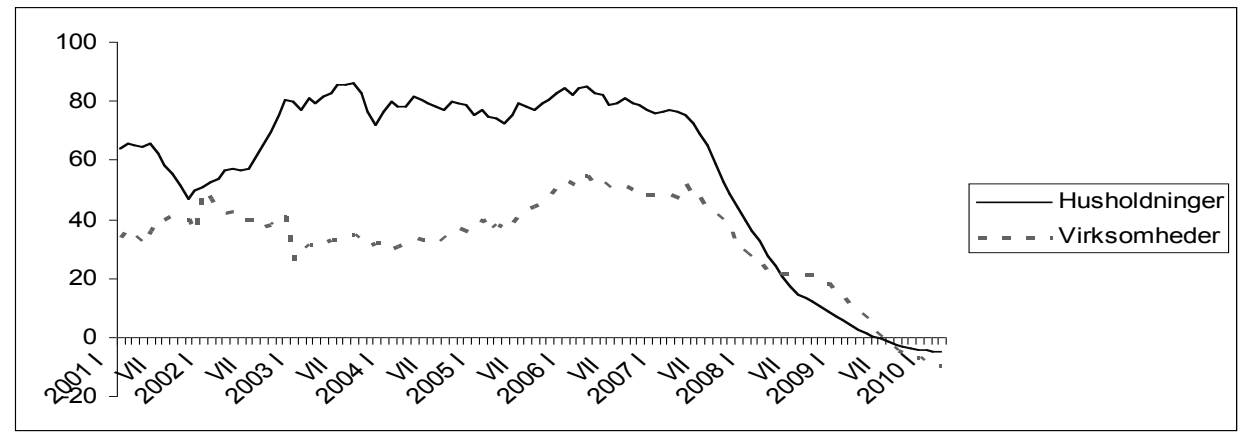

tentiale, dels skyldtes det strukturelle reformer i forbindelse med det lange træk mod optagelse i EU i 2004 og dels, og sandelig ikke mindst, skyldtes det banksystemets fødsel.

Før 2000 var banksystemet langt fra allemands eje og var mere orienteret mod servicering af kunder længere østpå, men det ændrede sig med især vestlige, primært svenske, såsom svenske Swedbank og SEB, bankers indtræden. Pludselig blev det muligt for almindelige letter at låne, og det gjorde de i meget voldsomt omfang, tilskyndet af lave renter, men endnu mere af, at det plud- selig, efter at have været umuligt i Sovjettiden, kunne lade sig gøre at få sin egen bil eller flytte i egen bolig. Lånene var for 90 pcts. vedkommende i udenlandsk valuta, primært euro.

Det kan være svært at beskrive, hvor stærke ønskerne om denne forbrugsfrihed var, når man som dansker er vant til lånemuligheder, men der var vel nærmest tale om en beruselse, og som det ses af figur 2, så var udlånsvæksten enorm.

Den voldsomme ekspansion af kreditgivningen skabte dels EU's største boom i markedet for fast 


\section{BAGGRUND}

Figur 3: Betalingsbalancens løbende poster i pct. af BNP

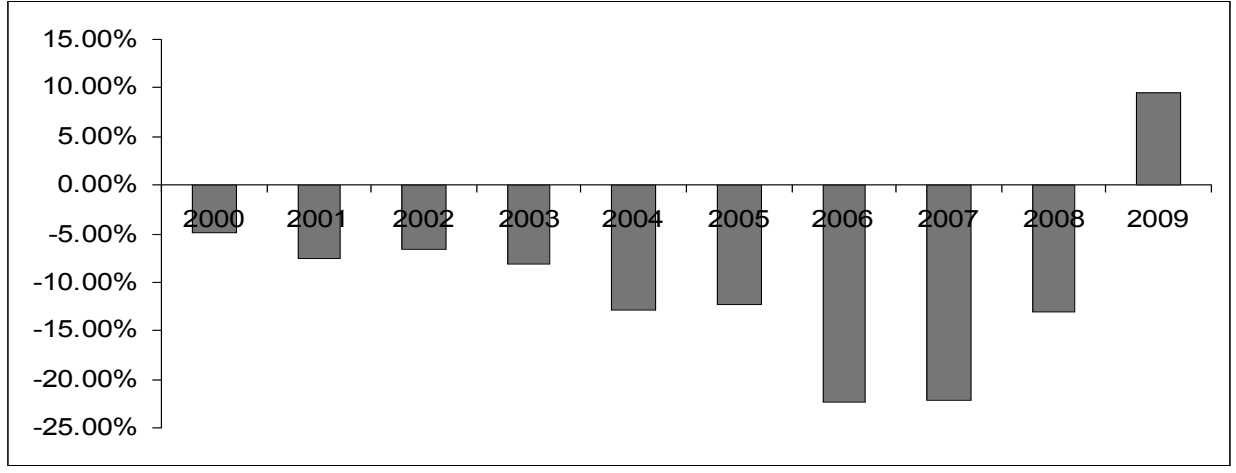

Figur 4: Arbejdsløshedsprocent

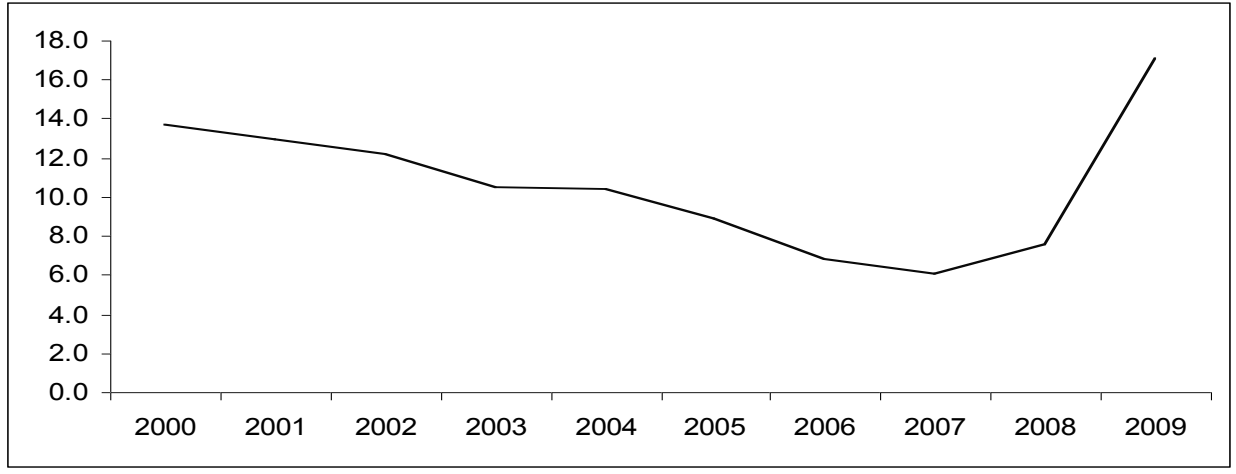

ejendom med pristigninger på 60 pct. flere år i træk og dels et forbrugsboom, der via sit store indhold af importerede varer (fx biler) medførte unionens største betalingsbalanceunderskud på 25 pct. af BNP.

Yderligere ubalancer blev skabt. Den voldsomme økonomiske aktivitet skabte et stort behov for arbejdskraft, ikke mindst til byggeindustrien og detailhandelen. Det, sammenholdt med emigration til især Irland, England og Sverige efter EUmedlemskabet, medførte et stort fald i arbejdsløsheden, hvilket fra 2005-06 begyndte at føre til flaskehalsproblemer.

Sådanne flaskehalsproblemer, kombineret med en økonomi i højeste gear og yderst decentrale lønforhandlinger, førte til massive lønstigninger, igen unionens største på op til 35 pct. på årsbasis.

Sådanne massive lønstigninger kan naturligvis ikke matches af tilsvarende produktivitetsstigninger, hvorfor disse for virksomhederne stigende omkostninger bliver væltet 
Figur 5: Årlig lønstigningstakt

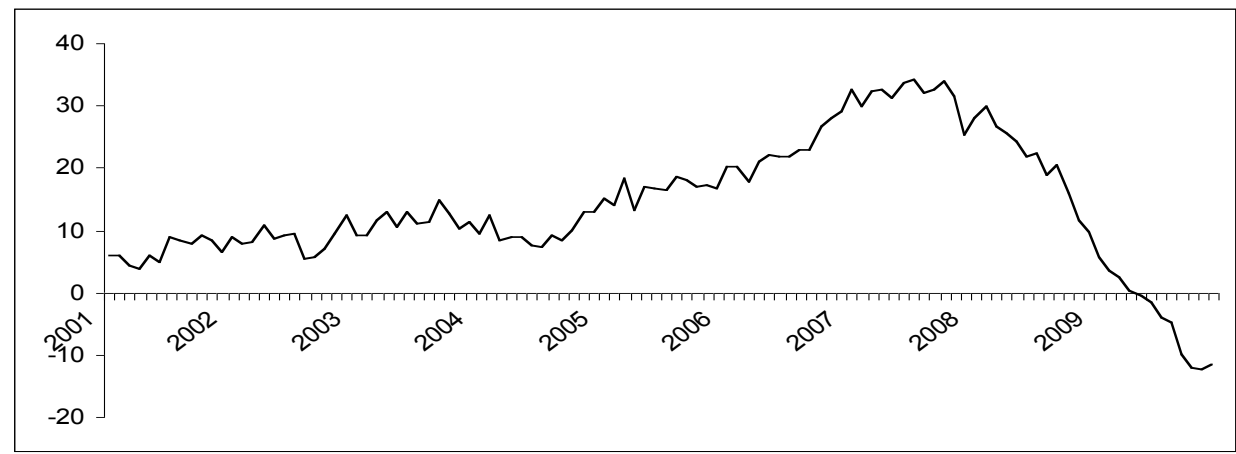

Figur 6: Inflation

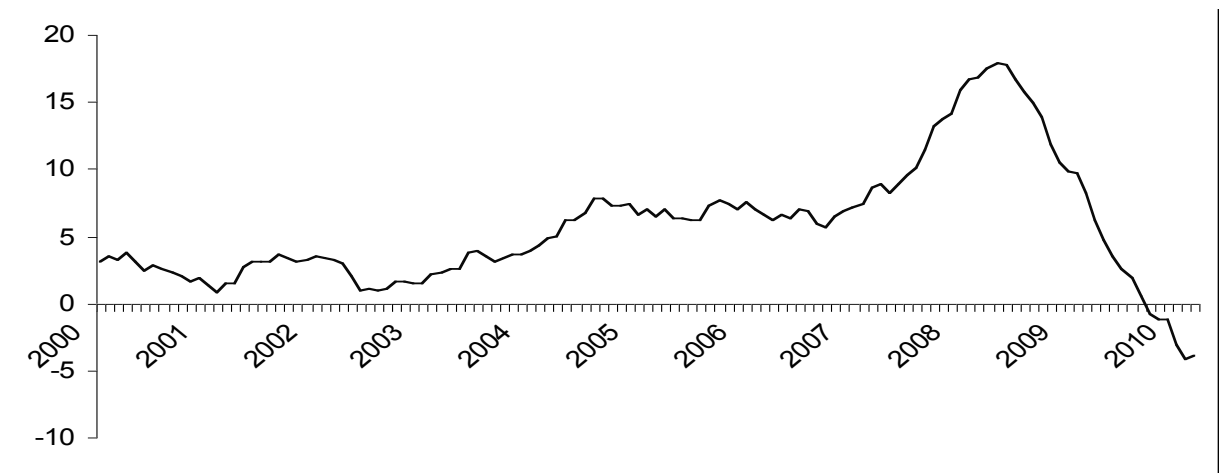

over på priserne med stigende inflation til følge. Det er muligvis nu en kende monotont, men Letland skabte også unionens højeste inflation, der nåede 17.9 pct. i maj 2008.

Såfremt der uddeltes medaljer for $\varnothing$ konomiske ubalancer, ville Letland i overheating-perioden 2004-07 have vundet guld for $ø$ konomisk vækst, lønstigningstakt, inflation, kredittilvækst, boligprisstigninger, betalingsbalanceunderskud samt den største private gældsætning i Østeuropa.

Et yderst relevant spørgsmål er selvfølgelig derfor, hvorfor udviklingen var så meget mere ekstrem $\mathrm{i}$ Letland, og det er emnet for næste afsnit.

De økonomiske vækstrater var såmænd ikke så langt efter Letlands i de to andre baltiske lande, og det var denne eksplosive vækst, der gav dem betegnelsen 'De Baltiske Tigre'.

Estland havde en kreditekspansion næsten på højde med Letlands, mens Litauens var noget mere behersket, men stadig voldsom. Svaret 
Figur 7: Offentlige udgifter pr. kvartal, mill. lettiske lats

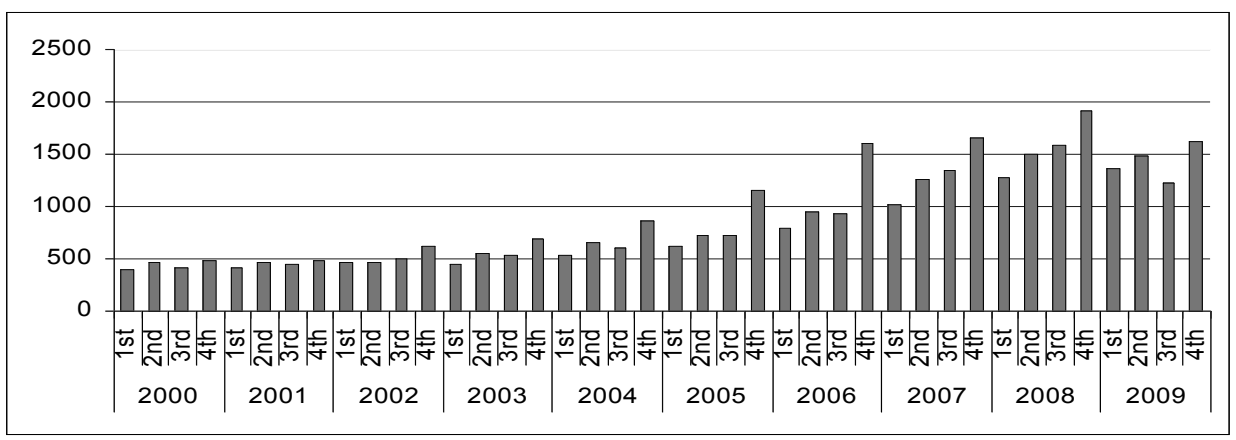

på spørgsmålet skal søges i finanspolitikken. Med så høje vækstrater og så drastisk faldende arbejsløshed stiger skatteindtægterne meget voldsomt. Idet det var den private sektor, der drev økonomien, havde en fornuftig finanspolitik forsøgt at lægge en dæmper på den økonomiske aktivitet via opbygning af et offentligt budgetoverskud, og det gjorde man da også i Estland, hvorimod Letland valgte en stærkt konjunkturmedløbende finanspolitik, hvor hver eneste ekstra skattekrone blev brugt - og mere til:

Selv i 2007, da boomet var på sit højeste og havde varet i omtrent otte år, havde staten et budgetunderskud. Denne konjunkturmedløbende politik skabte yderligere aktivitet i en allerede overophedet økonomi, bidrog til ubalancerne og kan bedst karakteriseres som aldeles uansvarlig for ikke at sige inkompetent. Intet forsvar? Ikke ud over det stærke ønske om indkomstkonvergens - der er i Letland en udbredt nervøsitet for, at vedvarende ind- komstforskelle melem øst og vest vil resultere i fortsat emigration, $o g$ at dette er en trussel mod selve den lettiske stat.

Men figur 7 skulle gerne vise, hvor uansvarlig finanspolitikken har været. Som det ses, udviser de offentlige udgifter betydelige sæsonudsving, især for 2004-08, med fjerde kvartal som kvartalet, hvor udgifterne topper: Ekstra skatteindtægter skulle 'brændes af', fordi man ikke ville se ens bevillinger skåret året efter, men det er også et resultat af en svag forvaltning og altid svage lettiske regeringskoalitioner, hvor politiske dividender skulle betales - overskydende skatteindtægter skulle fordeles mellem ministerierne i forhold til hvilke partier, der leverede ministrene.

Det bør også retfærdigvis nævnes, at den konstante fremgang havde skabt en jubeloptimisme og en tro på, at lønningerne ville fortsætte med at stige stærkt, at huspriser ikke kunne falde etc. Dette er ikke ulig situationen i de andre baltiske lande 
(eller for den sags skyld i Danmark, dog i mindre omfang), men uden at kunne føre bevis derfor må jeg nævne, at den lettiske mentalitet er meget 'boom-bust' - så overoptimistiske man var i 'de fede år', som de kaldes her, så overpessimistiske er man nu.

Læg dertil et i hvert fald dengang dårligt økonomisk-politisk debatklima, hvor advarsler om ubalancer blev anset for nærmest upatriotiske. Lars Christensen, Danske Banks chefanalytiker for Østeuropa og en mand, der har sine meningers mod, var alt andet end populær i Letland for sine analyser. En artikel, jeg selv skrev i 2007 endte med en mindre valutakrise, et opkald fra centralbankdirektøren samt et besøg af Sikkerhedspolitiet.

\section{Med $200 \mathrm{~km}$ i timen ind i en mur}

Sådan beskrev Letlands finansminister og tidligere centralbankdirektør og premierminister, Einars Repše, den nedsmeltning af den lettiske $\varnothing$ konomi, der startede med udgangen af 2007, accelererede i 2008 og slog ud i lys lue i 2009, og årsagen skal ses i den internationale finanskrise. Det lettiske boom var som beskrevet et massivt lånefinansieret eftespørgselsboom, og det er således ikke så sært, at når verden rammes af en finanskrise, så rammer det specielt hårdt lande, der har været meget afhængige af billig og rigelig kredit, såsom USA, Irland, Spanien, men også de tre baltiske lande med Letland i spidsen.

Kort fortalt bragte 2008 en slags 'undoing the past' - udlån skrumpede voldsomt ind (figur 2), hvilket medførte et kollaps i byggesektoren, i huspriserne og i detailhandelen. Den deraf følgende mindre økonomiske aktivitet (figur 1) førte meget hurtigt til stigende arbejdsløshed (figur 4). Den tidligere store efterspørgsel efter arbejdskraft er nu et massivt overudbud af arbejdskraft med lønfald til følge (figur 5), og faldende lønninger er lig faldende omkostninger, hvorfor også priserne er faldende (figur 6). Og det er atter olympisk: Letland har p.t. den mest negative økonomiske vækst, det største kredit- og boligpriskollaps, de største lønfald og den mest negative inflation i EU.

Det er dels som følge af, at låneboblen bristede, men det skyldes også en markant ændring i forbrugsog opsparingsmønstret hos befolkningen. Hvor privatforbruget i 200407 i enkelte år steg mere end indkomsterne, så har krisen flyttet forbrug til opsparing. Dette mindsker efterspørgslen i samfundet og accentuerer således den negative økonomiske vækst, og er også et resultat af 'boom-bust' mentaliteten.

Også finanspolitikken bidrager negativt. Som nævnt var den stærkt konjunkturmedløbende i 2004-07, og det tvinger den til at fortsætte på den måde, men i nedgangstider $\mathrm{i}$ form af massive offentlige nedskæ- 
ringer. Med den negative økonomiske vækst er skattegrundlaget voldsomt mindsket, og for ikke at skabe et alt for gabende hul i statsfinanserne er udgifterne tvunget til at følge med ned, også selvom dette skaber mindre økonomisk aktivitet.

\section{Parex}

En tredje faktor (ud over finanspolitikken og kreditboomet) gør Letland speciel, og det er Parex Bank, der blev grundlagt af Valerij Kargin og Viktor Krasovitjkij, de to første personer, der i Sovjetunionens sidste dage fik tilladelse til at etablere en kommerciel bank. Parex var således lettisk ejet og specialiserede sig i starten i at være den sikre havn for formuer fra andre ekssovjetrepublikker, og banken voksede sig til Letlands tredjestørste efter Swedbank og SEB.

Da den internationale finanskrise i 2008 fik individuelle EU-lande til at indføre garantier for indskud, blev Parex ramt hårdt, idet indskud i svenske banker i Letland var garanteret fra Sverige, og indskud i Parex begyndte at blive taget ud i hastigt tempo. Banken så sig i en likviditetskrise og måtte anmode den lettiske stat om at blive nationaliseret, men timingen for Letland var den værst tænkelige, idet dette fandt sted i oktober 2008, kort efter at Lehman Brothers var kollapset i USA, og alverdens finansmarkeder var frosset. Hvor skulle Letland finde lånefinan- siering til en rekapitalisering af $\mathrm{Pa}$ rex og til et hastigt voksende statsbudgetunderskud? De finansielle markeder var en umulighed, hvorfor Letland tyede til forhandlinger med IMF og EU, hvilket udmøntede sig i en 27-måneders stand-by aftale i december 2008 omfattende 7,5 mia. euro, hvilket er intet mindre end 35 pct. af Letlands BNP for 2008. EU var klart den største långiver.

Det er et meget stort beløb i forhold til Letlands økonomiske størrelse, men selvfølgelig en bagatel for EU og IMF. Størrelsen skal nok ses som udtryk for, at Letland for enhver pris skulle reddes. Den internationale finansielle situation i slutningen af 2008 var så anspændt, at såfremt Letland ikke havde modtaget denne pakke, så ville landet have været ude af stand til at betale lønninger og pensioner i januar 2009 og således være insolvent, og det må antages, at banksystemet og den lettiske valuta ville være kollapset i kølvandet herpå. Læg dertil IMF's og især EU's helt store bekymring, nemlig smittespredning fra Letland først til Litauen og Estland, dernæst til Ungarn, Ukraine m.fl. og dernæst til de lande, hvis banker opererer i disse lande, dvs. Sverige, Østrig, Tyskland etc. Det er tydeligt, at uanset omkostningerne, så måtte Letland ikke gå ned på det tidspunkt, da følgerne ville have været uoverskuelige. Dette forklarer nok også, at IMF accepterede det lettiske krav - ultimatum - nemlig, at aftalen 
skulle bygges op om en bevarelse af den faste valutakurs og have som exitstrategi at indføre euroen i 2012.

\section{Fast valutakurs $=$ det ellevte bud}

Danmark har haft en fast valutakurs siden 1982, først i forhold til D-marken, og nu til euroen, men det er vist ikke noget, den enkelte spekulerer så meget over. I Letland er man meget mere bevidst, også blandt lægfolk, om den faste valutakurs. Dels er det helt normalt at holde noget af sin opsparing i udenlandsk valuta, låne i udenlandsk valuta samt handle fx boliger deri.

Efter uafhængigheden i august 1991 opererede Letland med den russiske (sovjetiske) rubel, indtil man i maj 1992 introducerede den lettiske rubel. Fra marts 1993 begyndte man så (re)introduktionen af den lettiske lats, der i marts 1994 blev låst til IMF's særlige trækningsrettighed, og dette blev ændret til en binding til euro fra januar 2005 .

Den faste valutakurs betragtes som et anker, der sikrer stabilitet, og det er korrekt, at den hjalp med at nedbringe inflationen, der i 1992 nåede 952 pct. - Letland var det første østeuropæiske land, hvor inflationen kom under 10 pct. Det er svært for udenforstående at forstå, hvor meget den faste valutakurs betyder, men det var indtil krisen næmest tabuiseret at diskutere ' $\mathrm{D}$ ordet' - devaluering. Og det var da også netop opridsningen af, at en overophedning kunne nødvendiggøre en devaluering, der giv mig visse problemer. Det hænger dels sammen med, at valutaen just som landet stadig er ny - det er en del af identiteten, men det hænger nok også sammen med, at den erfaring man har med devalueringer ikke er små devalueringer på 3-5-8 pct. som Danmark prøvede det i 1970'erne, men i stedet massive devalueringer som fx den russiske rubel i 1998 , hvor konsekvenserne var massiv inflation og en destruktion af købekraften af ens rubler. Desuden skal den faste valutakurs ses i lyset af ønsket om yderligere integration.

Indlemmelse i eurozonen er ikke blot et pengepolitisk træk, der vil slette potentiel devaluering, det er også yderligere integration i EU og ligger i forlængelse af EU-medlemskab og inddragelse i Schengen-samarbejdet, der begge, sammen med NATO-medlemskab, bringer Letland længere væk fra Rusland.

\section{Intern devaluering}

I skrivende stund står Letland så med en økonomi, der er skrumpet ca. 26 pct. siden toppen i fjerde kvartal 2007, og som er på niveau med andet kvartal 2004; man kan således lidt letkøbt sige, at al den vækst, som EU-medlemskabet skabte, er væk. Desuden står man med en arbejdsløshed på omkring 20 pct. og uden udsigt til en hurtig vending i økonomien. 


\section{BAGGRUND}

Forbrugerne kan ikke forventes at ville trække økonomien, da de stadig lider af for store lån optaget $\mathrm{i}$ 'de fede år', og da frygten for arbejdsløshed fremmer opsparing på forbrugets bekostning. Virksomhederne kan heller ikke ventes at drive værket, da fremtidsudsigterne ser sorte ud, og da realrenten for at låne til investeringer er høj, idet deflationen gør, at lån skal betales tilbage med indtægter fra varer, der må påregnes at skulle sælges til lavere priser.

Finanspolitikken er lammet, da den som beskrevet var alt for ødsel i opgangstiderne, og det er faktisk kun IMF-EU pakken, der muliggør lidt finanspolitisk råderum. Letland ville muligivs være $\mathrm{i}$ stand til at låne på de internationale kapitalmarkeder her i 2010, men det var en umulighed i 2009. Uden IMF-EU pakken ville landet således have været tvunget til et balanceret budget, hvilket ville have krævet endnu flere drakoniske besparelser.

Diskussionsemnet er således eksporten, og debatten går på, om man via en (ekstern) devaluering kan forøge konkurrenceevnen og dermed eksporten samt lokal importsubstitution. Som nævnt har Letland kategorisk afvist denne vej, hvilket en lang række internationale (og enkelte lokale) økonomer stiller sig uforstående overfor.

Jeg er ikke som mange letter religiøs omkring valutakursen, men jeg mener, der er et forsvar for ikke at devaluere: at det risikerer at blive en ukontrollabel devaluering. Såfremt en devaluering skaber forventning om yderligere devaluering, kan man snildt tænke sig et 'virtuelt bankrun', hvor vi alle klikker os ud af lettisk valuta. Såfremt centralbanken ikke kan modstå et sådant pres, vil forventningerne kunne blive selvopfyldende. Som nævnt er alle i Letland fuldt ud klar over den faste valutakurs, og dette øger netop risikoen for et sådant 'run'.

I stedet forsøger Letland en såkaldt intern devaluering, hvor man via sænknng af lønninger skulle se en afsmitning på priserne og dermed på konkurrenceevnen. Som det ses af figur $5 \operatorname{og} 6$, så falder lønningerne faktisk, og det gør priserne også, og dette er endnu en demonstration af den lettiske økonomis bemærkelsesværdige (men perverse) fleksibilitet.

Konkurrenceevnen, der uomtvisteligt blev svækket i højinflationsdagene, bliver således forbedret, men som altid ved en intern devaluering er spørgsmålet, om det sker hurtigt nok, og om omfanget vil være tilstrækkeligt. Den interne devaluering er trods alt drevet af $h ø j$ arbejdsløshed, og det er i sig selv en voldsom pris at betale.

Det er således stadig et åbent spørgsmål, om strategien ender succesrigt, men visse konklusioner kan allerede nu drages. Mange udenforstående har spurgt, hvorfor den massive arbejdsløshed og den barske 
lønnedgang ikke har ført til demonstrationer og social uro. Dertil er at svare, at a) manglen på fagforeninger gør, at der ikke er nogen naturlig organisator eller leder for sådanne demonstrationer, b) det er ikke 'the Latvian way' - letter er som mange andre østeuropæere ret så stoiske og bider pinen i sig, og c) tiderne er i dag trods alt langt bedre end i starten af 1990'erne efter uafhængigheden, desuden, d) emigration virker som en ventil og skaffer dels løn til en selv dels til ens familie og e) nogle er som i 1990'erne gået over til subsistenslandbrug.

Men Letlands strategi bør også stå som et varsel for, hvad der venter Grækenland, der også har set sin konkurrenceevne smuldre og som grundet et offentligt overforbrug nu er tvunget til basalt set samme kur som Letland og det uden at have en ekstern devaluering som en mulighed, idet jeg antager, at exit fra eurozonen og genindførelse af en national valuta, der så kan devalueres er noget nær praktisk umulig. Hvis Letland ikke kan gennemføre den interne devaluering med succes, så ser det meget sort ud for Grækenland (og Portugal, Spanien og Italien), der ikke har samme fleksible økonomier som Letland. Der er således al mulig grund til at følge udviklingen i Letland meget nøje.

Givet det mildest talt turbulente år, som 2009 var, hvor der var massive devalueringsrygter i juni, hvor det ofte blev spået, at IMF ville pak- ke sammen og forlade Letland, og hvor skatteforslag blev stillet og pillet ned inden for få timer eller dage, så har IMF-EU pakken været en succes: Pakken er stadig intakt, statsbudgettet hænger sammen, økonomien har nået bunden, og budgetunderskuddene er inden for de aftalte rammer. Det er ganske bemærkelsesværdigt taget i betragtning, at den siddende regeringskoalition som altid i Letland - er svag. Det må formodes, at intet parti tør være det, der vælter pakken, omend det parlamentsvalg, der skal afholdes tidligt i oktober 2010, givetvis vil skabe en perlerække af mere eller mindre populistiske forslag.

\section{Fremtidig vakst?}

Letlands økonomi er på dramatisk vis bombet tilbage til sit 2004-niveau, hvilket som nævnt dog stadig er langt højere end i transitionstiden i de tidlige 1990'ere, men hvad med fremtidig vækst?

Jeg vil mene, at det måske mest skadelige resultat af 'de fede år' var, at de maskerede for strukturelle reformer, som Letland behøver. Det er vel forståeligt, at man efter indlemmelsen i EU i 2004 led af en vis reformtræthed, men der er stadig ikke og har aldrig rigtig været en klar accept af, hvorfor Letland er så fattigt et land i en EU-sammenhæng.

Der er selvfølgelig flere faktorer, blandt dem korruption som så ofte bliver nævnt, men jeg vil argumente- 
re for, at uddannelseniveauet er for lavt. Her forsvarer lokale kommentatorer sig med, at en meget høj andel af unge studerende får en højere uddannelse, og det er korrekt, at kvantitativt er Letland med langt fremme. Kvalitativt halter det dog, og et lille eksempel kan måske illustrere dette. Tre betydningsfulde industrier i Letland er træ og trævarer, transport og tekstiler. Den første er en naturresource, den anden et resultat af geografisk beliggenhed mellem Rusland/SNG og Vesteuropa og den tredje et resultat af lave lønninger. Men ingen af de tre er videnstunge industrier. Letland har hverken Nokia eller Vestas, fordi landet ganske enkelt mangler tilstrækkelig human kapital.

Letland vil selvfølgelig opleve vækst igen, og den vil nok så småt starte $i$ anden halvdel af 2010, men der er ikke noget der tyder på, at høje vækstrater kommer tilbage. Vejen frem er strukturelle reformer, hvilket er langt lettere sagt end gjort, men en nødvendig første forudsætning er en forståelse for, hvor manglerne er. Og hvorfor så ikke bide stoltheden i sig og se på 'best practice' eksempler? De forefindes i rigt mål på den vestlige side af Østersøen.

Letland var bestemt ikke ene om at opleve et kreditboom, og det er ikke ene om de efterfølgende tømmermænd, men landet skiller sig ud ved de meget dramatiske størrelser, der var på ubalancerne.

Boblen kunne ikke være undgået, men de mest destruktive effekter heraf kunne været dæmpet, om især finanspolitikken havde været konjunkturmodløbende i stedet for konjunkturmedløbende. Letland ville også have draget fordel af en mere åben og saglig debat, og landet har lidt og lider under den udprægede mangel på tænketanke tilknyttet partier, fagforeninger og andre organsationer. Det giver et analyse- og debatniveau, der til tider er skræmmende lavt.

Fokus i Letland har det seneste år ikke været på det lange sigt - det har været på den umiddelbare overlevelse, dvs. undgå insolvens, undgå bankkrak og undgå en devaluering, og landet kan undskyldes for denne prioritering. Men nu er det så småt på tide at se fremad og forhåbentlig indse, at 'de fede år' også medførte et delvist tabt årti, når det gælder strukturreformer.

Morten Hansen er Head of Economics Department ved Stockholm School of Economics in Riga. 